\title{
When the Pendulum is stuck! - Invisible Agonists and Babies in Prison INTRODUCTION
}

People matter, this is the claim by Goodman, Page, and Phelps (2017). In 'Breaking the

Pendulum', Philip Goodman, Joshua Page and Michelle Phelps use three axioms about penal development to explain the visible effects of people they label 'agonists'. The pendulum metaphor has been used within scholarship in criminology, and the sociology of punishment, to illustrate broad trends with the role of the prison (as well as criminal justice systems) that can appear to swing between retribution and rehabilitation. While there is no evidence of large scale transformations in penal policy relating to babies in prison, the pendulum isn't broken. In particular in their revision of Breaking the Pendulum, Page, Phelps and Goodman (2019) encourage discovering how marginal positions and actors become part of the field to transform criminal justice.

There is an international consensus that babies can be accommodated by prisons to live with their mothers from new-born. This situation appears to be settled, however their existence is invisible and to some it could be "unthinkable" to have babies in prison. Politicians and reformers are continually struggling to shape criminal justice policies to influence what is "thinkable" or "unthinkable". The agonist perspective has been used to explore the contexts of the United States (Goodman, Page and Phelps, 2017), Scotland (Page, Phelps and Goodman, 2019) and Canada (Goodman and Dawe, 2015). The significance of this paper is the role of international alliances and the work of people within the United Nations, as well as activists in Australia and Canada. In particular, concerns from people at an international level have led to important developments within the human rights framework that affect women and children.

\section{EXPLORING THE PENAL FIELD}

The concept of a 'field' is central to understanding the agonist perspective promoted by Goodman Page and Phelps (2017, 2019). Metaphorically the 'field' is not any patch of ground but is akin to a football field with players who have to stick to its boundaries. The field relates to academic work by Pierre Bourdieu who explained that actors are constantly battling to either safeguard or improve their position (Bourdieu and Wacquant, 1992). The penal field can be situated at national, state, local or international levels. The boundaries depend on the dynamics, structure and capital in relation to the field. It is important to note that concerns about macro-level trends, or critical events do not automatically produce transformations and are not necessarily included within the penal field (Goodman, Page and Phelps, 2017). Central to understanding agonists is their relationship to the field, status and ability to define or impact conceptions of justice (Goodman, Page and Phelps, 2017). Who gets to play in the penal field, at any level, is difficult to ascertain and there is evidence of systematic exclusions. For example, with racial politics of juvenile justice in the US, 'generations of black agonists have struggled to institutionalize antiracism (Ward, 2019). The focus needs to be with actors who seek to shape punishment policy or practice and not necessarily the success of their campaigns.

The visibility of actors in the penal field is important because it is through their struggles that legitimate or illegitimate forms of punishment can be defined (Page, Phelps and Goodman, 2019). Bourdieu explains how battles depend on the power of its players (Bourdieu and Waquant, 1992). This means populations who need representation from agonists, such as babies in prison are not automatically excluded from the penal field because they have no voice.

Babies in prison are obviously a marginal concern in relation to the whole of imprisoned populations around the world. Due to this position in the penal field it has been easier to identify players and the boundaries of the fields they have played in. Other problems with analysing this minority population have been difficulties with identifying the goals of criminal justice institutions, crime and punishment understandings or visions of lawmakers. Despite these limitations, it is possible to identify a penal field and actors who are operating 
to transform the lives of women and their babies or dependent children.

Significantly, in 2016, David Cameron (Prime Minister of United Kingdom) announced, "it was terrible to think of infants spending time behind bars" (BBC News, 2016). At the time, he was advocating a review about conditions of women in prison, rather than aiming to transform the practice of having mother and baby units in female prisons. In the same year a charity called Birth Companions publically launched a 'Birth Charter for Women in Prisons in England and Wales' which recommended reform for local policies in prisons (Birth Companions, 2016). Important players in a local context are visible; however the impact from their attention to the topic of babies in prison is unobservable. If struggles existed at this time in England and Wales, they have been kept 'out of bounds' and this invisibility has continued the status quo.

The agonistic perspective is useful for identifying struggles only if they are visible. The claim is that despite appearances of stability, consensus is often conflictual. The case of babies in prison is useful because it is possible to use it to analyse struggles that have existed within an international penal field.

\section{INTERNATIONAL CONTEXT}

The pendulum logic has rarely been used to describe female criminal justice. Despite this, the global rise in mass incarceration for women is a well understood phenomenon of recent decades (Carlen, 2013; Carlen and Tombs, 2006; Chesney and Lind, 2013). Feminist criminologists have had an important role in challenging the masculinist bias and dehumanising systems in their activism. The primary focus for struggles relating to women involved in criminal justice has been to encourage the penal field to respond to their specific needs, issues and realities of their lives (Whalley and Hackett, 2017).

Concerning babies in prison it is not known how nation-state policies and practices have changed or whether they have remained the same. Internationally there is no known accurate data of the number of babies born in prison or the amount of dependent infants with their mothers. The age limit of children is different throughout the world and this evidence can illustrate the lack of consistency with the treatment of this minority population. Infants up to the age of 6 years of age can legitimately live with their mothers in Germany and are accommodated in self-contained flats, however in India children up to the age of 6 years old are in prisons without any pre-school education (Crewe, 2020). The only country that does not accommodate new-borns, babies or children in prison is Norway (Crewe, 2020). Central to the agonist perspective is to identify people or organisations that have been instrumental in penal development. On an international level it is possible to identify developments within the international human rights framework that have the potential to significantly reduce the number of incarcerated women and babies. The first international instrument devoted to addressing women with dependent children in prison was the United Nations Rules for the Treatment of Women Prisoners and Non-Custodial Measures for Women Offenders that are known as the Bangkok Rules 2010 (Crewe, 2017). These rules further international human rights for female offenders, even though they are classified by lawyers as 'soft law' or 'non-state' legislation. In documenting their struggle during consultations in the draft phase of the Bangkok Rules, Debbie Kilroy and Kim Pate (2010) usefully illustrate key tensions that can help to refine the agnostic perspective. This has enabled a consideration of the three axioms by Goodman, Page and Phelps (2017) to analyse the international penal field relevant for the topic of babies in prison.

\section{INTERNATIONAL AGONISTS}

The first claim is that penal development is the product of struggle between actors with different types and amounts of power (Goodman, Page and Phelps, 2017). Kim Pate was denied access to work within prisons in Canada. In 2001, she was the Chief Executive of Canadian Association of Elizabeth Fry Societies (CAEFS) and joined with the Native Women's Association of Canada to file a complaint with the Canadian Human Rights Commission (Kilroy and Pate, 2010). The commission confirmed these accusations and found there was a breach of human rights of female prisoners. Following this, a number of international bodies and the United Nations Human Rights Committee became involved to criticise the Canadian Government. This experience led Kim making contact and attending an international conference held by an Australian activist organisation that had also been denied access to work in prisons to support women. Having joined forces, both organisations issued a statement to the $11^{\text {th }} \mathrm{UN}$ Congress on Crime Prevention and Criminal Justice meeting in Bangkok, 2010 (Kilroy and Pate, 2010). 
The appearance of Kim Pate and Debbie Kilroy in the international penal field was made possible by having a combination of financial, social and cultural capital as well as status gained through their respective local, national and international networks. Sisters Inside is an organisation that worked within female prisons for many years in Australia; however it was forced to choose between advocating for human rights or providing service provision (Kilroy and Pate, 2010). This Australian organisation was not only prevented from working in female prisons, but due to national and international advocacy was able to bring together activists from around the world to share their experiences. Using the principles of abolition, and activist strategies, both Pate and Kilroy were agonists who contested national policies and used this experience to enter the margins of the international penal field.

The work of non-governmental organisations at an international level is an important and relevant penal field for all incarcerated populations. The appearance of Kilroy and Pate at an international level meant they received consultation status within the United Nations, as well as, an ability to participate with international processes that affects the lives of incarcerated women and children around the world. In preparation for the International Expert Group meeting they developed alternative rules to reflect their experiences of supporting women and address human rights (Kilroy and Pate, 2010). This version of events is not widely known. Not only were these proposals ignored at the international meeting, but the origin of the Bangkok Rules is officially attributed to Her Royal Highness Princess Bajrakityapha of Thailand (Crewe, 2017).

\section{INTERNATIONAL STRUGGLES}

The second claim advocated in Breaking the Pendulum has been revised to encourage understanding that consensus is conflictual. This means exploring how people struggle to create priorities, policies and institutional practices. It is clear that the appearance of Kim Pate and Debbie Kilroy in the international penal field was due to a combination of status, capital and they formed a powerful collaboration. Following the disappointment from having a draft version of the Bangkok Rules ignored and the lack of visibility with their contributions, these agonists disappeared from the dominant international penal field. In particular, they explained that the Bangkok Rules in their draft form did not adequately take into account children or recognise a need for judicial review of decisions made by prison authorities that affect the separation of mothers and their children (Kilroy and Pate, 2010). 10 years after their introduction, Kim Pate has left the penal field altogether and is now a senator in Canada.

The Bangkok Rules (United Nations General Assembly, 2011) have been a significant development due to their acknowledgement of specific issues (some relevant for all prisoners) women in prison and their sentencing. In recognition of the concept of 'conflictual consensus', it is important to identify the perspective of activists and scholars who are continuing to struggle to improve human rights and transform imprisonment for women and children. There is recognition that the Bangkok Rules (2010) have given hope (Barberet, 2014; Carlen, 2013; Cain, 2015; Van-Gundy et al, 2013). The main problem is how they are not legally binding and therefore need visibility to empower humanitarian appeals, global pressures and innovation (Brysk, 2013). Organisations such as Sisters Inside are continuing to network internationally and have links with international abolitionists.

The international penal field is important for putting pressure on nation-states as well as providing interpretations of complex rules that consist of a hierarchy of legislation. Special Rapporteurs are appointed by the Human Rights Council to act independently and give advice about all aspects of human rights implementation. A report by Juan E Mendez (Special Rapporteur on Torture) was publicised through specialist networks in the social media. He gave a helpful interpretation of human rights and identified specific aspects of the Bangkok Rules (2010). For example, the report highlighted how the use of restraints for all pregnant women in prison should be interpreted as a form of punishment, which threatens the health of women and amounts to torture or ill-treatment (UN, 2016). In particular, this document widened the scope of international rules relevant for babies in prison by associating them with the Convention Against Torture and Other Cruel, Inhuman or Degrading Treatment or Punishment. Unlike agonists at a local or national level, Special Rapporteurs rely on others to negotiate and the focus of their struggles is mainly content related.

'Breaking the Pendulum', identifies how large-scale trends affect contestation over punishment and local outcomes. The main point of this final claim is to identify why struggles exist and whether they are determined by individuals, power, policy, status or the 
penal field (Goodman, Page and Phelps, 2017). In the case of babies in prison it is difficult to distinguish what exactly affects struggles because of their lack of visibility. This is the first time this topic has been researched from a sociological point of view. There is a dearth of scholarly literature, and the few researchers who have written about this subject have focused on: mother and baby unit's admission policies (Sufrin, Crenin and Chang, 2009), attachment and separation of mother and babies (Price, 2005) or conditions for pregnant women (Abbott, 2015). This literature does not reflect broader changes that have affected other prison populations such as sentencing of women, the attitude of the public towards babies in prison or changes that could lead to reducing the number of babies and young infants in prison. The paucity of attention by academics, politicians or activists has been useful for identifying how struggles are determined by the power, status and individuals on the margins of the international penal field.

\section{CONCLUSION}

It is ironic that claims advocated in 'Breaking the Pendulum', and its subsequent symposium, can be useful to explore a situation of no visible changes. Feminists have affected trends relating to women in prison around the world. In particular, they have used scholarship, activism and political pressure to draw attention towards the support that is needed for women in criminal justice and penal fields. Unfortunately the broad trend towards genderresponsive policies and practices has led to criticisms because other priorities have meant the needs of women have been managed as risks (Hannah-Moffat, 2010). Agonists who represent women that do not advocate abolition of imprisonment or struggle have been criticised and labelled carceral feminists (Whalley and Hacket, 2017). The broad trends that have recognised women have left issues relating to children and babies behind. The lack of attention towards this minority population means their visibility can lead to more questions than answers. For example, Deborah Jiang-Stein was born in prison and has written about her personal struggles in a book called, "Prison Baby: A Memoir" (Jiang-Stein, 2013). She found out about her birth in prison later in life and her book highlights many personal dilemmas such as: Should she have been allowed to form a bond with her prison mother? Was it correct that she was separated?

There is no doubt mass imprisonment in and the rise in neo-liberal policies or practices means that the focus of struggles is concentrated on issues that affect large numbers of people. The case of Kilroy and Pate (2010) highlights that international non-governmental organisations are key for leading battles in the international, national and local penal fields. It has been possible for rules such as the Bangkok Rules (2010) and their association with other important human rights to determine policy. Despite this, there are limited resources and people who have sufficient power or status to enter battles in the penal field on behalf of babies and children. This situation renders babies in prison invisible which in-turn maintains the status quo.

The pendulum is stuck: however there appears to be no momentum to get it going! The agonist perspective is useful for highlighting that even though the Prime Minister of the UK, charities, non-governmental organisations, and the Special Rapporteur on torture, has been involved with this topic : the status quo remains. Babies in prison will continue to rely on human rights frameworks and all struggles relating to them are localised, private and invisible.

\section{REFERENCES}

Abbott, L. (2015). A pregnant pause. In L. Baldwin (Ed.), Mothering Justice: working with mothers in criminal and social justice settings. East Sussex, UK: Waterside Press.

Barberet, R. Women, Crime and Criminal Justice: a global enquiry. (2014). New York: Routledge.

BBC News. Prisons 'overhaul'announced by David Cameron. (2016). Retrieved from http://www.bbc.co.uk/news/uk-35518477

Birth Companions. Birth Charter for women in prisons in England and Wales. Retrieved from www.birthcompanions.org.uk, 2016.

Bourdieu, Pierre, and Loic J. D. Waquant. An Invitation to Reflexive Sociology. Chicago: University of Chicago Press, 1992.

Brysk, A. Changing hearts and minds: sexual politics and human rights. In T. Risse, S. Ropp, \& K. Sikkink (Eds.), The persistent power of human rights: from commitment to compliance. (2013). Cambridge, UK: Cambridge University Press. 
Cain, C. State of the estate: women in prison's report on the women's custodial estate (2nd ed.). (2015). Retrieved from http://www.womeninprison.org.uk

Carlen, Pat and Tombs, J. “ Reconfigurations of Penality: The Ongoing Case of the Women's Imprisonment and Reintegration Industries." Theoretical Criminology Vol 10, Issue 3 (2006): $337-360$.

Carlen, Pat." Preface.” In Carlton, B and Segrave, M. (Eds). Women Exiting Prison: Critical Essays on Gender, Post-Release Support and Survival. Oxon, UK: Routledge, 2013.

Chesney-Lind, Meda and Morash, Merry "Transformative Feminist Criminology: A Critical Re-thinking of a Discipline.” Critical Criminology Vol 21 (2013): 287-304.

Crewe, Helen. Female Prisons Around the World: Facts and Figures about Women in Prison, LAP: Lambert Academic Publishing (2020).

Crewe, Helen. "Can Therapeutic Jurisprudence Improve the Rights of Female Prisoners?" In Halder, D and Jaishankar, K. Therapeutic Jurisprudence and Overcoming Violence Against Women IGI Global (2017).

Goodman, Phillip, and Meghan, Dawe. "Prisoners, Cows and Abattoirs: The Closing of Canada's Prison Farms as a Political Penal Drama." The British Journal of Criminology 56, no 4 (2015): 793-812.

Goodman, Phillip, Joshua Page, and Michelle Phelps. Breaking the Pendulum: The Long Struggle Over Criminal Justice. New York: Oxford University Press, 2017.

\section{Hannah-Moffat, K Sacrosanct or flawed: risk accountability and Gender-responsive penal politics, Current Issues in Criminal Justice. (2010) Vol 22: No 2}

Kilory, Debbie and Pate, Kim. "Activism Around Gendered Penal Practices". Current Issues in Criminal Justice Vol 22, Issue 2 (2010), 325-343.

Page, Joshua; Phelps, Michelle, and Goodman, Philip. "Consensus in the Penal Field?

Revisiting Breaking the Pendulum". Law and Social Inquiry Vol 44, Issue 3 (2019), 822-827. Price S Maternity services for women in prison: a descriptive study. (2005) British Journal of Midwifery, Vol: 13 No 6.

Sufrin $\mathrm{C}$, Crenin $\mathrm{M}$ and Chang $\mathrm{J}$ Incarcerated women and abortion provision: a survey of correctional health providers, Perspectives on Sexual and Reproductive Health. (2009) Vol: 41, No 1.

United Nations General Assembly. (2011). Resolution adopted by the General Assembly: 65/229 United Nations Rules for the Treatment of Women Prisoners and Non-custodial Measures for Women Offenders (the Bangkok Rules). Sixty-fifth session: agenda item 105.

United Nations General Assembly. Report of the Special Rapporteur on torture and other cruel, inhuman or degrading treatment or punishment. Human Rights Council, thirty-first session Agenda item 3. (2016). Retrieved from http://www.ohchr.org/EN/NewsEvents/Pages/DisplayNews.aspx? NewsID $=17187 \&$ LangID $=\mathrm{E}$

Van Gundy, A., \& Buamann-Grau, A. Women, incarceration and human rights violations. (2013). Farnham, UK: Ashgate Publishing Company.

Ward, Geoff. "Contention and the Pendulum Pivot: Weighting Equal Justice". Law and Social Inquiry Vol 44, Issue 3 (2019), 806 - 813.

Whalley, Elizabeth and Hackett, Colleen "Carceral Feminisms: the Abolitionist Project and Undoing Dominant Feminisms" Contemporary Justice Review Vol 20, Issue 4 (2017): 456473. 
